\title{
CLIMATE CHANGE AND MORAL RESPECT FOR THE NATURE - AN ANTROPOCENTRIC PERSPECTIVE
}

\author{
Adam Plachciak ${ }^{365}$ \\ https://doi.org/10.31410/itema.2018.1086
}

\begin{abstract}
The purpose of the paper is to present the need of ethical concern in the context of climate change as one of the main environmental problems. The attention was focused on moral responsibility for the nature from anthropocentric perspective.
\end{abstract}

Keywords: climate change, ethics, anthropocentrism, biocentrism, ecocentrism.

\section{INTRODUCTION}

$\mathrm{D}$ uring the period of two last decades, climate change have become one of the most pressing issue facing different circles of policymakers, scientists, philosophers and even theologians. However, it is still not an easy problem to deal with. The production of greenhouse gases (GHGs) is deeply rooted in the economy that the modern society has developed since the industrial revolution.

However, climate change cannot be properly understood and fully comprehended without taking into account its axiological approach. Especially it is important in the situation where the serious threats and irreversible harms occur to the Earth's ecosystems. In fact, every aspect of climate change should be shaped by the ethical debate from scientific research, political decisions through the individual choices [1].

The main purpose of the research is to find out the answer to some of the uprising questions around the idea of our moral obligations towards natural environment in the context of climate change. It should be beyond any discussion even if global climate change is not the result of human made carbon dioxide concentration in the atmosphere. The probability it might cause such a change should encourage people to limit greenhouse gas emissions. ${ }^{366}$

In this context, some important questions should be answered in the area of our moral obligations towards contemporary global warming, such as: Has climate change already happened? If so, to what extend are we morally responsible for it? What principles and standards should be chosen to stop or at least minimize human actions causing climate change? What criteria of justice should be taken to preserve future generations against the results of climate change?

It is widely accepted in climate change discussions that only human interests should be considered in formulating moral obligations and duties towards natural resources. Though, there are ethicists who argue that also nonhuman benefits should be respected when dealing

\footnotetext{
${ }^{365}$ Wroclaw University of Economics (Poland), Faculty of Economics, Management and Tourism in Jelenia Gora, ul. Nowowiejska 3, Poland

366 For further reading: [2], [3], [4].
} 
with the threats of climate change. In this research focus is on the issue of moral responsibility for the nature from anthropocentric perspective. The paper has a descriptive character. Its method is strictly submitted to the literature used in the text.

\section{GLOBAL CLIMATE CHANGE IN HISTORICAL DATA}

The emission of green house gases is probably one of the biggest reasons of the environmental damage which globally have ever happened. There are generally the following problems created by concentration of green house gases in the atmosphere: (1) Global climate warming (or global overheating); (2) Decrease of the ozone layer; (3) Growing concentration of acid in water and (4) Atrophy of natural resources caused by acid rains and dioxide sulphur [5].

The scientific research of climate change began already in $19^{\text {th }}$ century when some natural phenomena, such as the ice ages, started to be considered as a potential result of green house effect. Joseph Fourier (1768 - 1830) was one of the earliest forerunners in the history who took the advantage to investigate the causes of climate change on the Earth. Living some years later John Tyndall (1820 - 1893) [6], the Irish physicist from the Royal Institute of London discovered which exact components had been absorbing the infra-red radiation. The phenomenal analyses in the area of carbon dioxide (CO2) impact on climate change were also made by the Swedish physical chemist Svante Arthur Arrhenius (1859 - 1927) [7]. His estimations led him to conclude that present human-produced carbon dioxide emissions, from fossil fuel burning and other combustion processes, were large enough to create global warming. At the same time another scientist - Thomas Chrowder Chamberlin (1843 - 1928) [8] - was one of the first climatologists who developed a theory which improved that progressive decrease of carbon dioxide in the atmosphere had been the main reason of the glacial era on the Earth in the past. However, a decisive moment for the international comprehension of hazardous climate change should actually be dated at the beginning of the sixties in the last century, especially after publishing Charles David Keeling's [9] investigations on carbon dioxide in the Earth's atmosphere above Hawaii and Antarctica.

In 1988 The Intergovernmental Panel on Climate Change, as one of the first scientific intergovernmental authorities, was established under the auspicious of The United Nations and The World Meteorological Organization (WMO). In 1992 during The World Submit in Rio de Janeiro, The United Nation Framework Convention on Climate Change was signed up by the members of the Conference. Implementation of the UNFCCC led finally to The Kyoto Report in $1997 .^{367}$

Talking about the threats of climate change as one of the main environmental problems, there are two crucial questions. The first one belongs to the empirical or scientific order. In this case we ask, whether climate change is a natural phenomena or to what extent it is a result of human activity. The other question is focused rather more on our moral obligations towards natural environment. We are expected to give answers about what we regard as our obligations and duties towards the nature, or how we understand human - nature relationship. When it comes

\footnotetext{
367 Right now, it is well documented that the energy balance in the atmosphere has been distorted by two components. First, there are greenhouse gasses such as: carbon dioxide (CO2), methane (CH4), nitrous oxides (N2O), sulphur hexafluoride (SF6), hydrofluorocarbons (HFCs), perfluorocarbons (PFCs). Those gasses capture a vast amount of energy emitted from the surface of the Earth, at the same time keeping it in our atmosphere and warming the Planet. Second, there are aerosols, playing the role of miniscule particles being accumulated in the air. At first, they cause a cooling effect on the Earth - because they mirror solar rays back into the cosmic space. But also, they are sort of like black carbon that causes warming effect. The issue is well documented in: [10].
} 
to solve those dilemmas of what is or how we should treat the nature, we deal with moral questions. And this perspective is the base of the following research.

\section{CLIMATE CHANGE AND THE ANTHROPOCENTRIC DISTRIBUTION OF RESOURCES}

At the beginning we shall consider the anthropocentric orientation in regard to environmental problems. In a philosophical discourse anthropocentrists usually postulate humans to be the most important entities in the universe. They argue that all other natural beings are only means to human ends. According to anthropocentric worldview: (1) environment is a source for humans, used as needed; (2) human health and well-being plays a central role in decision making; (3) people are environmental managers of natural resources; (4) human-nature stability depends on governmental regulations, taxes, legislations and political procedures. ${ }^{368}$

In regard to the problems of climate change anthropocentric environmental ethicists try to answer two main questions. These are: (1) How to ensure that people who suffer most from the consequences of climate change are protected to survive such consequences? (2) How to guarantee that our posterities would not suffer terrible results of climate change created by present generations? In other words, environmental ethics with its anthropocentric concern is focused on contemporary people as rational entities who are responsible for the fate of future generations. Such ethics ought to provide principles and standards which would strengthen moral behave to stop or at least minimize human actions resulting in unpredictable consequences of climate change and global warming [14].

In this case, any environmental studies from anthropocentric point of view should basically be focused on just distribution of goods, access to natural resources and economic security. In this context John Rawls writes: Justice is the first virtue of social institutions, as truth is of systems of thought. A theory however elegant and economical must be rejected or revised if it is untrue; likewise laws and institutions no matter how efficient and well-arranged must be reformed or abolished if they are unjust.(...) The truth and justice are uncompromising [15]. At the same time he puts the question: On what grounds $<\ldots>$ do we distinguish between mankind and other living things and regard the constraints of justice as holding only in our relation to human beings? [16] And then he suggests: The natural answer seems to be that it is precisely that moral persons who are entitled to equal justice. Moral persons are distinguished by two features: first, they are capable of having $\langle\ldots\rangle$ a conception of their good $\langle\ldots\rangle$; and second, they are capable of having a sense of justice [17]. In his argumentation it has been drawn a straight line leading to the conclusion that only humankind can posses a conception of good and a sense of justice. In a similar way - his opponent - Michael Walzer - sees the problem, when he writes: One characteristic above all is central to my argument. We are (all of us) culture-producing creatures. We make and inhabit meaningful worlds [18].

In some ways, the authors of the Brundtland Report when constructing a definition of sustainable development choose a sort of anthropocentric view of sustainability. They write sustainable development is a development that meets the needs of the present without compromising the ability of future generations to meet their own needs [19]. Regarding a question of distributive justice, the Brundtland Commission pointed on an "inequality" as the main Planet's "environmental" problem. The document states: A growing number of the urban

\footnotetext{
${ }^{368}$ In contrast to anthropocentrism, the biocentric and ecocenric orientations consider humans to be a particular species of animal, yet without greater intrinsic value than any of other species or organisms. For further reading, see: [11], [12], [13].
} 
poor suffer a high frequency of diseases; most are environmentally based and could be prevented or dramatically reduced through relatively small investments [20]. This account proves that poor people basically live in poor environments. The environmental threats which occur in different parts of the world touch everyone equally, but usually the poorest are the most distressed. They are the weakest to afford protecting themselves against it. In a similar way Laura Pulido describes this with the words: $I t<\ldots>$ is the poor and marginalized of the world who often bear the brunt of pollution and resource degradation - whether a toxic dump, a lack of arable land, or global climate change - simply because they are more vulnerable and lack alternatives [21]. This may suggest that the environment, we are part of, is an exact type of goods that society must justly distribute among its members. This is also proved by Andrew Dobson, when he writes: $<\ldots>$ "environmental justice" does not $<\ldots>$ mean "justice to the environment", but refers rather to a just distribution of environmental goods and beds among human populations [22]. It seems that public policy should play a fundamental role in promoting the idea of environmental justice based on mutual respect and fairness for all human races, free from prejudice and discrimination. This type of ethics finds a satisfaction with a liberty system and human rights.

Yet, the problem appears when we want to choose the criteria of distributive justice. Obviously, it is impossible to distinguish a concrete - all equally satisfying - principle of distribution. Furthermore, the anthropocentric orientation provides additional problems, especially in relation to just distribution of goods to future generations [23]. Nevertheless, the principle of justice can be defended when we consider biological human needs such as breathing, oxygen, health, water, cultivable soil - those goods can be anticipated in a long period of time ahead. So it seems reasonable to pave way between anthropocentric and ecocentric/biocentric orientation concerning moral obligations towards the nature. ${ }^{369}$

\section{CONCLUSIONS}

The process of green house gas emissions has started at least 650000 years ago, but the levels of carbon dioxide have risen almost 200 times faster over the past 50 years than at any other time during this period. If such a course of climate warming goes on in the nearest future, we might expect unpredictable consequences of natural disasters like droughts, floods, famines, increasingly destructive hurricanes etc. The results of sea level rise will strike people globally; some of them are already affected by it. The presence of moral discourse within climate change policy should be unquestionable because it always leads us to answer three main questions: (1) What is our responsibility to the non-human world? (2) What is our responsibility to the human order? (3) How should we care for the future? In this case it is necessary to consider much wider than the anthropocentric orientation.

\section{REFERENCES}

[1] Gardiner, S. M., Caney, S., Jamieson, Shue, D. H., (ed.), (2007) Climate Ethics: Essential Readings, Oxford University Press, Oxford.

[2] Gardiner, S. M., (2011) A Perfect Moral Storm. The Ethical Tragedy of Climate Change, Oxford University Press, Oxford.

\footnotetext{
${ }^{369}$ Robyn Eckersley in her environmental philosophy suggests emancipatory solution. She writes: ecological emancipatory theory must accommodate all human emancipatory struggles within a broader, ecological framework $\langle\ldots\rangle$ and $\langle\ldots>$ all differently situated others (human and nonhuman) ought to be free to unfold in their distinctive ways and therefore should not to be subjected to unjustified policies and decisions that impede such unfolding [24]. For more reading see: [25], [26].
} 
[3] Skimshire, S., (ed.), (2010) Future Ethics. Climate Change and Apocalyptic Imagination, Continuum International Publishing Group, New York.

[4] Tremmel, J., Robinson, K., (2014) Climate Ethics. Environmental Justice and Climate Change, I.B. Tauris \& Co Ltd, London - New York.

[5] Malucha, M., (2010) Przyczyny zmian klimatu. Próba eksplikacji głównych problemów, (in:) Borys, T., Fiedor, B., Ekonomia. Gospodarka a środowisko, Prace Naukowe Uniwersytetu Ekonomicznego we Wrocławiu (No. 11), Wydawnictwo Uniwersytetu Ekonomicznego we Wrocławiu, Wrocław, p. 62.

[6] Tyndall, T., (1861) On the Absorption and Radiation of Heat by Gases and Vapors and on the Physical Connection of Radiation, Absorption and Conduction, „Philosophical Magazine Series Four" (No. 146).

[7] Arhenius, S. A., (1903) Lehrbuch der kosmischen physic, Hirschel Publishing House, Lipsk.

[8] Chamberlin, T. C., (1899) An Attempt to Frame a Working Hypothesis of the Cause of Global Periods on an Atmospheric Basis, „Journal of Geology” (No. 7).

[9] Keeling, Ch. D., (1970) Is Carbon Dioxide from Fossil Fuel Changing Man's Environment? „Proceedings of the American Philosophical Society” (No. 1).

[10] Baran, A., Janik, A., Ryszko, A., (2011) Handel emisjami w teorii o praktyce, Wydawnictwo Fachowe Cedetu.pl, Warszawa, pp. 31 - 126.

[11] Naess, A., (1988) Deep ecology and ultimate premises, "The Ecologist" (No. 18), pp.128131.

[12] Devall, B., Sessions, G., (1988) Deep Ecology: Living as if Nature Mattered, Peregrine Smith Publisher, Salt Lake City.

[13] Baird, C. J., (1980) Animal Liberation: A Triangular Affair, "Environmental Ethics" 1980, (No. 2), (Vol. 4), pp. 311-338.

[14] Okoye, Ch. A., (2012) The Problem of Climate Change: A Study of Anthropocentric Environmental Ethics, "Research on Humanities and Social Sciences" (Vol. 9), p. 137.

[15] Rawls, J., (1973) A Theory of Justice, Oxford University Press, Oxford, p. 15.

[16] Rawls, J., (1973) A Theory of Justice, Oxford University Press, Oxford, p. 504.

[17] Rawls, J., (1973) A Theory of Justice, Oxford University Press, Oxford, p. 505.

[18] Walzer, M., (1983) Spheres of Justice: A Defense of Pluralism and Equality, Blackwell, Oxford, p. 314.

[19] The World Commission on Environment and Development. Our Common Future, (1987) Oxford University Press, Oxford, p. 43.

[20] The World Commission on Environment and Development. Our Common Future, (1987) Oxford University Press, Oxford, p. 239.

[21] Polios, L., (1996) Environmentalism and Economic Justice, University of Arizona Press, Tucson, pp. XV-XVI.

[22] Dobson, A, (1998) Justice and the Environment. Conceptions of Environmental Sustainability and Dimensions of Social Justice, Oxford University Press, Oxford, p. 20.

[23] Heilbroner, R., (1981) What has Posterity Ever Done for Me, [in:] E. Partridge (ed.), Responsibilities to Future Generations, Prometheus Book, New York, p. 49.

[24] Eckersley R., (1992) Environmentalism and Political Theory: Toward an Ecocentric Approach, Suny Press, Albany, p. 70.

[25] Plachciak, A., (2009) Sustainable Development - the Way of Building Just Society, "Economics and Sociology" (No. 1), (Vol. 2), pp. 108-109.

[26] Maedowcroft, J., (2005) From Well-fare State to Ecostate, [in:] J. Berry, R. Eckersley, the State and the Global Ecological Crises, MIT Press, London 2005. pp. 3 - 23. 